\title{
A Comparative Study on Financial Performance of the Participants in Indonesia Sustainability Reporting Awards
}

\section{Hatane Semuel ${ }^{1}$ (i) | Saarce Elsye Hatane ${ }^{2 *}$ (i) $\mid$ Cyndy Fransisca $^{3} \mid$ Josua Tarigan 4 (1) | Jean-Marc Dautrey ${ }^{5}$}

\author{
${ }^{1}$ Universitas Kristen Petra, Department of Marketing, Surabaya, Indonesia \\ ${ }^{2}$ Universitas Kristen Petra, Department of Business Accounting, Surabaya, Indonesia \\ 3Universitas Kristen Petra, Department of Business Accounting, Surabaya, Indonesia \\ ${ }^{4}$ Universitas Kristen Petra, Department of International Business Accounting, Surabaya, \\ Indonesia \\ ${ }^{5}$ Stamford International University, Bangkok, Thailand
}
* Correspondence to: Saarce Elsye Hatane, Universitas Kristen Petra, Faculty of Business and Economics, Department of Business Accounting, Jalan Siwalankerto 121-131, Surabaya, Jawa Timur, 60235, Indonesia.
E-mail: elsyehat@petra.ac.id

\begin{abstract}
The main objective of this research is to analyze the financial performance of companies that have participated in Indonesia Sustainability Reporting Awards (ISRA) competitions in 2009-2017, both regularly and temporarily. This study also analyzes the differences in financial performance in terms of industrial sector factors and the number of workers. This research applies secondary data, which is carried out with independent t-test and multivariate test. Companies that consistently participate in ISRA competitions have a smaller level of leverage, and more exceptional ability to generate operating cash. Companies with fewer than two thousand employees are more productive than companies with ten thousand employees. However, when the number of employees is more than ten thousand people, productivity managing assets is even better. It seems that investors appreciate small companies more. Compared to companies in the banking sector, companies in the manufacturing and nonmanufacturing industries have more substantial debts, more productive assets, and higher stock market values. It seems that investors appreciate this ISRA competition more for non-banking companies.
\end{abstract}

Keywords: corporate social responsibility, financial performance, Indonesia Sustainability Reporting Awards, sustainability report.

Article info: Received 9 March 2019 | revised 23 April 2019 | accepted 29 May 2019

Recommended citation: Semuel, H., Hatane, S. E., Fransisca, C., Tarigan, J., \& Dautrey, J.-M. (2019). A Comparative Study on Financial Performance of the Participants in Indonesia Sustainability Reporting Awards. Indonesian Journal of Sustainability Accounting and Management, 3(1), 95-108. https://doi.org/10.28992/ijsam.v3i1.84.

\section{INTRODUCTION}

Corporate social responsibility (CSR) has become the spotlight in business because companies are evaluated not only on financial performance but also on social responsibility; thus, many companies take socially 
responsible actions to gain legitimacy and competitive advantage (Rhou et al., 2016). Many companies in developing countries start to design appropriate CSR initiatives which can increase their practices in CSR, but a lot of companies still consider CSR as a separate part from the company's strategy and values (Jamali, 2014).

According to Hussain (2015), there are increasing demand and pressure from stakeholders towards the companies to reduce negative impacts on the environment and society. Moreover, they demand the companies be more transparent and accountable in terms of business process and financial statement reporting. Servaes \& Tamayo (2013) state that CSR has a positive impact on firm's value. Therefore, companies which can fulfill social obligations by being socially responsible may increase their values.

Companies that conduct CSR practices must disclose sustainability reports as a primary tool for communicating CSR (Romero et al., 2014). The sustainability report is the process of measuring and communicating sustainability performance and one of the responsible reporting methods to the stakeholders for the company's social, environmental and business performance to achieve sustainable development (GRI, 2013). Sustainable development may able to increase company value, which is influenced by the relationship quality between internal and external stakeholders. Unlike mandatory financial disclosures, sustainability reports disclosure is voluntary and is considered as an act of transparency (de Villiers \& Marques, 2016). Cormier et al. (2011) show that sustainability reports disclosure reduces information asymmetry and stock volatility. Similarly, El Ghoul et al. (2011) state that companies with higher social disclosure will experience risk reduction and a broader investor base.

Since 2005, the National Center for Sustainability Reporting (NCSR) and Indonesian Institute of Accountants (IAI) have established the Indonesia Sustainability Reporting Awards (SWAOnline, 2013). Indonesia Sustainability Reporting Awards (ISRA) is created to give awards to companies which have compiled and disclosed the sustainability report. The existence of ISRA is expected to give companies incentives to continue developing sustainability reports as a form of social responsibility so that they can shape fostered corporate governance and have an impact on their financial performances.

Companies begin to publish sustainability reports as a strategy to improve their financial performance. This case is supported by the research from Reddy \& Gordon (2010), which shows that sustainability reporting has a significant effect on profitability increase. Companies which publish sustainability reporting may increase the company's attention towards the environment and company's ability to be able to maintain talented human resources, managing corporate wealth, consumers, as well as increasing stakeholders' trust which makes the company's profit to increase. Therefore, to establish a strategy to maximize shareholders' wealth, the board tends to increase and report on the company's environmental and social activities, to benefit the stakeholders (Jizi, 2017). The appropriate sustainability report disclosure is to be following the stakeholders' expectations that the company higher opportunities in the future and the realization of sustainable development.

The dominant stakeholder theory in the CSR literature is profit-oriented activities, which affects broader stakeholder groups (Anas et al., 2015). The effect is raised by the company's intention to not only focus on the investors' wealth but also to address the concerns to non-profit oriented stakeholders such as regulators, employees and the public (Anas et al., 2015). Pérez et al. (2013) suggest that stakeholder-based CSR enables companies to identify strengths and business areas that need greater visibility to be successful. One of the strategies to foster the relationship with corporate stakeholders is to disclose sustainability reports, as well as social and environmental dimensions. Sustainability reports disclosure will fulfill the stakeholder's expectations and will produce a harmonious relationship between the company and stakeholders in the long-term (Kurniawan, 2018). 
The second theory which essential of the sustainable report is the legitimacy theory. If the stakeholder theory is upheld by stakeholder accountability, the legitimacy theory based on the existence of social contracts that occur between companies and communities where companies which operate legally are accepted. Legitimacy theory is used to understand the aspects of CSR deeper and to evaluate every decision taken by the company (Duff, 2017). Moreover, companies can legitimize their operations by having good CSR practices. Fundamentally, good CSR practices appreciated (Anas et al., 2015). If the company achieved an award for good CSR practices, the legitimacy gap between companies and communities would be minuscule; thus, companies will be more encouraged to be more transparent.

Chakroun et al. (2017) reveal that there is a positive relationship between financial performance and CSR disclosure. Syamni et al. (2018) give the evidence that implementing CSR will influence the company's profitability because stakeholders will be willing to buy the company's products and assume that small fraction of the company profit will be donated to environmental care activities. CSR is a way of communicating with stakeholders (Mehralian et al., 2016). Khojastehpour \& Johns (2014) suggest that customers will tend to pay a higher price for products or services provided by companies which implement CSR; thus, the consumers can help the companies in building its reputation and profitability (Lin et al., 2015; Hasan \& Yun, 2017).

Bilbao-Terol et al. (2019) researched by testing companies which implement CSR towards market book value. The study revealed that a sustainable company becomes the top position in the market, attracting investors and stakeholders. Kim et al. (2014) add that CSR performance affects company value in the market. Consistent results were also found by Bajic \& Yurtoglu (2018) that strong CSR predicts market value from the social dimension.

Hsu \& Chen (2015) states that companies which have positive CSR performance will experience the reduction in credit risk, the spread of bonds, and the risk of bankruptcy. In Giannarakis (2014) study reveals CSR is negatively related to the leverage coefficient. The negative coefficient displays fostered company conditions. Chakroun et al. (2017) state that there is a positive effect between leverage and CSR disclosure because CSR can be a way of monitoring creditors. This can be a concern for investors and lenders as indicators of financial risk because CSR is a crucial component of the internal and external control systems to ensure bankruptcy and debt risk accurately.

Chtourou \& Triki (2017) provides evidence that there is a positive relationship between CSR and financial performance. This case makes the application of CSR to improve financial performance. Nyeadi et al. (2018) also find evidence that CSR positively spurs financial performance. Martin et al. (2018) reveal that corporate social responsibility disclosure has a positive and significant effect on return on asset (ROA).

This study describes companies' financial performance, which participates in the Indonesia Sustainability Reporting Awards (both consistent and inconsistent). Furthermore, this study also compares the financial performance of companies that have joined the ISRA, related to the industrial sector and the number of employees.

\section{METHODS}

The data used in this research are secondary data. All the financial performance deploys in this study taken from Bloomberg. The number of companies used in this study is 12 public companies which participated in the ISRA award from 2009-2017. Tests conducted on the companies are done by conducting different tests to see the implications of the company condition in reporting sustainability reports while simultaneously following the ISRA award and inconsistent. 
Table 1 Company Samples Studied

\begin{tabular}{llccc}
\hline \multicolumn{1}{c}{ Code } & \multicolumn{1}{c}{ Company Name } & Year & Sector & Employee range \\
\hline ANTM & PT Antam (Persero) Tbk & $2009-2017$ & 2 & $2,000-10,000$ \\
JSMR & PT Jasa Marga & $2009-2017$ & 2 & $2,000-10,000$ \\
TLKM & PT Telekomunikasi Indonesia Tbk & $2009-2017$ & 2 & $>10,000$ \\
TINS & PT Timah (Persero) Tbk & $2009-2017$ & 2 & $2,000-10,000$ \\
PTBA & PT Bukit Asam (Persero) Tbk & $2009-2017$ & 2 & $2,000-10,000$ \\
SMCB & PT Holcim Indonesia Tbk & $2009-2017$ & 1 & $2,000-10,000$ \\
ASII & PT Astra International Tbk & $2009-2017$ & 1 & $>10,000$ \\
UNTR & PT United Tractors Tbk & $2009-2017$ & 2 & $>10,000$ \\
PGAS & PT Perusahaan Gas Negara (Persero) Tbk & $2009-2013$ & 2 & $<2,000$ \\
& & $2014-2017$ & 2 & $2,000-10,000$ \\
SMGR & PT Semen Indonesia (Persero) Tbk & $2009-2017$ & 1 & $2,000-10,000$ \\
INCO & PT Vale Indonesia Tbk & $2009-2017$ & 2 & $2,000-10,000$ \\
BBNI & PT Bank Negara Indonesia (Persero) Tbk & $2009-2017$ & 3 & $>10,000$ \\
\hline
\end{tabular}

This study compares the financial performance of the participants in ISRA. The dimensions of financial performance examined in this study are leverage, asset management, profitability, and market value. This study compares the performance dimension in three categories. First is based on the consistency in joining the ISRA: a consistent scale (1) and inconsistency scale (0). The second group is based on the business sector: manufacturing (1), non-manufacturing (2), and banking (3). Lastly, based on the size of the company, which is measured by the number of employees: <2,000 (1), 2,000-10,000 (2), and >10,000 (3).

In previous the studies, the ratio that is often used to assess company performance is profitability ratios and market value ratios; however, for other ratios such as leverage ratio, asset management ratio, leverage ratio, and liquidity ratio are still limited, and they are used together same in one study. Therefore, this study is inspired from the motivation to better complement research in the field of sustainable reports, especially in Indonesia, which will use four existing financial performance indicators, to enrich the research model of sustainability reports.

A normality test is conducted to ensure that the data sources collected are normally distributed. The data taken by the researcher is secondary data in which data taken comes from Bloomberg and the annual report. The independent $\mathrm{t}$-test is used to test the hypothesis $\mathrm{H}_{10} \mathrm{-H} 1 \mathrm{c}$, where the samples consist of 2 categories that are not correlated, namely participants consistently participate and those who do not always join in ISRA 20092017. The normality test is used to test whether the residuals produced have been normally distributed. However, even though the results are not normal, it can still be overcome by the bootstrap process. The criteria for decision making to see participants' differences that are consistent and inconsistent in this test are based on probability values. If the probability is (sig.) $>0.05$ then, there is no difference. If the likelihood is (sig.) < 0.05 then, there is a difference.

The multivariate test is used to test the hypothesis $\mathrm{H}_{2} \mathrm{a}-\mathrm{H} 2 \mathrm{C}$ and $\mathrm{H}_{3} \mathrm{a}-\mathrm{H} 3 \mathrm{C}$, where the samples of each hypothesis consist of 3 categories. For $\mathrm{H}_{2} \mathrm{a}-\mathrm{H} 2 \mathrm{~d}$, the sample consists of participants in the manufacturing, nonmanufacturing, and banking sectors. Whereas for $\mathrm{H} 3 \mathrm{a}-\mathrm{H} 3 \mathrm{c}$, the sample consisted of participants with an interval of the number of workers, namely: <2,000; 2,000-10,000; and >10,000. 


\section{RESULTS AND DISCUSSION}

Table 2 shows the descriptive of each variable deploy in this study. These results indicate that several companies in the observation period have negative profits. Analysis of inventory turnover and receivable turnover performance is only focused on non-banking companies. Meanwhile, some companies do not use long-term debts as funding sources. Besides, TINS companies, in 2013, 2014, and 2014 were unable to produce positive cash flow operating.

Table 2 Descriptive Results

\begin{tabular}{lccccc}
\hline \multicolumn{1}{c}{ Variables } & S.D. & Mean & Median & Minimum & Maximum \\
\hline FSIZE Assets & 1.251 & 8.406 & 3.007 & 4.856 & 7.093 \\
FSIZE Revenue & 4.827 & 3.84 & 1.652 & 3.692 & 2.601 \\
ROA & 7.901 & 9.857 & 9.046 & -5.504 & 38.458 \\
ROE & 12.812 & 18.807 & 17.057 & -9.937 & 66.241 \\
Profit Margin & 9.99 & 14.859 & 14.547 & -13.681 & 34.578 \\
NWC Turnover & 15.068 & 2.107 & 2.599 & -89.139 & 58.698 \\
Debt Ratio & 0.133 & 0.19 & 0.156 & 0.002 & 0.468 \\
Debt Equity Ratio & 0.349 & 0.413 & 0.323 & 0.002 & 1.74 \\
LTD Ratio & 0.115 & 0.127 & 0.103 & 0 & 0.398 \\
Market Book Ratio & 1.48 & 2.621 & 2.413 & 0.412 & 8.21 \\
PER & 29.727 & 19.835 & 15.393 & 0 & 298.333 \\
Inventory Turnover & 120.234 & 39.802 & 5.56 & 0 & 602.244 \\
Receivable Turnover & 4.952 & 8.018 & 8.69 & 0 & 18.543 \\
NFA Turnover & 4.64 & 3.305 & 1.993 & 0.341 & 36.543 \\
Asset Turnover & 0.339 & 0.69 & 0.703 & 0.091 & 1.553 \\
CFO/TA & 0.096 & 0.13 & 0.111 & -0.076 & 0.339 \\
\hline
\end{tabular}

Variables are deemed to fulfill normality if each group of ISRA and non-ISRA (not consistent as the ISRA participants) is fulfilled, meaning that if in a variable that has one normal ISRA group while the non-ISRA group is declared abnormal then the residual variable cannot be said to be normal. Residuals from each variable can be reported homo if the test value is $>0.05$. The table result shows that Ln NFA turnover does not pass the Heteroscedasticity test because it has a Levine value of $0.039(<0.05)$.

Table 3 Normality Test Result from Kolmogorov-Smirnov

\begin{tabular}{lccc}
\hline \multicolumn{1}{c}{ Variable } & Non-ISRA & ISRA & Heteroscedasticity (Levine) \\
\cline { 2 - 4 } & sig. & sig. & 0.974 \\
\hline FSIZE Assets & 0.055 & 0.001 & 0.784 \\
FSIZE Revenue & 0.016 & 0.000 & 0.703 \\
ROA & 0.020 & 0.200 & 0.557 \\
Profit Margin & 0.200 & 0.200 & 0.617 \\
Ln Market Value & 0.200 & 0.200 & 0.277 \\
Debt Ratio & 0.200 & 0.002 & 0.074 \\
Ln Market Book Ratio & 0.047 & 0.089 & 0.659 \\
Receivable Turnover & 0.074 & 0.010 & 0.140 \\
Asset Turnover & 0.200 & 0.200 & 0.039 \\
Ln NFA Turnover & 0.042 & 0.013 & \\
\hline
\end{tabular}


From the overall results of the Kolmogorov-Smirnov test, p-values of variables are mostly higher than 0.05 , therefore bootstrap in the difference test will be carried out to support the continuation of this study. Independent tests of the bootstrap t-test is used because the Kolmogorov-Smirnov results indicate that each group does not meet normality. The following are the results of the bootstrap test independent $\mathrm{t}$-test:

Table 4 Bootstrap Independent t-Test Results

\begin{tabular}{lcccc}
\hline \multicolumn{1}{c}{ Variable } & ISRA - Non-ISRA & Bias & Std. Error & Sig. \\
\hline ROA & 3.032 & -0.065 & 1.910 & 0.119 \\
ROE & 2.840 & -0.112 & 3.473 & 0.402 \\
Profit Margin & 3.350 & -0.110 & 2.263 & 0.148 \\
NWC Turnover & 1.450 & -0.051 & 2.220 & 0.508 \\
Debt Ratio & -0.089 & 0.002 & 0.034 & 0.012 \\
Debt Equity Ratio & -0.322 & 0.004 & 0.107 & 0.005 \\
LTD Ratio & -0.059 & 0.002 & 0.030 & 0.055 \\
Market Book Ratio & 0.281 & 0.003 & 0.350 & 0.420 \\
PER & 3.275 & 0.204 & 3.979 & 0.471 \\
Inventory Turnover & -58.281 & 0.557 & 36.780 & 0.131 \\
Receivable Turnover & 3.214 & 0.013 & 1.068 & 0.002 \\
NFA Turnover & -2.985 & 0.002 & 1.838 & 0.141 \\
Asset Turnover & 0.112 & -0.001 & 0.070 & 0.115 \\
CFO/TA & 0.047 & 0.000 & 0.021 & 0.023 \\
\hline
\end{tabular}

The bootstrap results show that the different financial performance of companies that consistently joined ISRA from the inconsistent ones. The loyal participants of ISRA use more equity in its financing activities, which makes them more liquid. Besides, their abilities to produce cash are higher than the inconsistent ISRA participants. The standard error is used to measure accuracy in predictions; the smaller the numbers, the more accurate the predictions (Sekaran \& Bougie, 2016).

The following data is the results of data processing performed for different test numbers of employees:

Table 5 Mean Difference Test Based on Number of Employees Groups

\begin{tabular}{|c|c|c|c|c|c|c|c|c|c|c|}
\hline $\begin{array}{c}\text { Dependent } \\
\text { Variable }\end{array}$ & $\begin{array}{l}\text { FSIZE } \\
\text { Assets }\end{array}$ & $\begin{array}{c}\text { FSIZE } \\
\text { Rev. }\end{array}$ & ROA & $\begin{array}{l}\text { Profit } \\
\text { Margin }\end{array}$ & $\begin{array}{l}\text { Ln } \\
\text { Market } \\
\text { Value }\end{array}$ & $\begin{array}{l}\text { Debt } \\
\text { Ratio }\end{array}$ & $\begin{array}{c}\text { Ln } \\
\text { Market } \\
\text { Book } \\
\text { Ratio } \\
\end{array}$ & $\begin{array}{l}\text { Rec. } \\
\text { Turn. }\end{array}$ & $\begin{array}{l}\text { Asset } \\
\text { Turn. }\end{array}$ & $\begin{array}{l}\text { Ln NFA } \\
\text { Turn. }\end{array}$ \\
\hline & $\begin{array}{c}\text { Mean } \\
\text { Diff. }\end{array}$ & $\begin{array}{c}\text { Mean } \\
\text { Diff. }\end{array}$ & $\begin{array}{c}\text { Mean } \\
\text { Diff. }\end{array}$ & $\begin{array}{c}\text { Mean } \\
\text { Diff. }\end{array}$ & $\begin{array}{c}\text { Mean } \\
\text { Diff. }\end{array}$ & $\begin{array}{c}\text { Mean } \\
\text { Diff. }\end{array}$ & $\begin{array}{c}\text { Mean } \\
\text { Diff. }\end{array}$ & $\begin{array}{c}\text { Mean } \\
\text { Diff. }\end{array}$ & $\begin{array}{c}\text { Mean } \\
\text { Diff. }\end{array}$ & $\begin{array}{c}\text { Mean } \\
\text { Diff. }\end{array}$ \\
\hline & $\begin{array}{l}\text { Sig. (t- } \\
\text { Test) }\end{array}$ & $\begin{array}{c}\text { Sig. (t- } \\
\text { Test) }\end{array}$ & $\begin{array}{l}\text { Sig. (t- } \\
\text { Test) }\end{array}$ & $\begin{array}{l}\text { Sig. }(t- \\
\text { Test) }\end{array}$ & $\begin{array}{l}\text { Sig. (t- } \\
\text { Test) }\end{array}$ & $\begin{array}{c}\text { Sig. (t- } \\
\text { Test) }\end{array}$ & $\begin{array}{l}\text { Sig. }(t- \\
\text { Test) }\end{array}$ & $\begin{array}{c}\text { Sig. (t- } \\
\text { Test) }\end{array}$ & $\begin{array}{l}\text { Sig. }(t- \\
\text { Test) }\end{array}$ & $\begin{array}{c}\text { Sig. (t- } \\
\text { Test) }\end{array}$ \\
\hline$<2,000-$ & 0.595 & 0.664 & 11.841 & 18.952 & 1.23 & 0.112 & 0.942 & 2.722 & -0.009 & -0.296 \\
\hline$(2,000-1,0000)$ & 0.004 & 0.001 & 0.000 & 0.000 & 0.000 & 0.057 & 0.003 & 0.000 & 0.977 & 0.144 \\
\hline$<2,000-$ & -1.423 & -1.17 & 12.927 & 15.967 & -0.805 & 0.166 & 0.762 & 3.481 & -0.034 & -0.757 \\
\hline$>10,000$ & 0.000 & 0.000 & 0.000 & 0.000 & 0.000 & 0.012 & 0.011 & 0.007 & 0.882 & 0.000 \\
\hline$(2,000-10,000)$ & -2.017 & -1.834 & 1.086 & -2.986 & -2.104 & 0.054 & -0.18 & 0.759 & -0.026 & -0.461 \\
\hline$->10,000$ & 0.000 & 0.000 & 0.689 & 0.219 & 0.000 & 0.064 & 0.159 & 0.793 & 0.943 & 0.027 \\
\hline
\end{tabular}

Table 5 shows that in most of the financial performances, companies with the smallest number of employees (less than 2,000 employees) are higher than the companies with the middle number of employees (in range of 2,000-10,000 employees). Moreover, companies with the biggest number of employees (more 
than 10,000 employees) have the highest assets, revenues, equities, market value, and net fixed assets' turnover.

In term of profitability, it is revealed that the smaller the number of employees in the companies, the higher the profitability in those companies. The productivity of fixed assets is found in large companies. However, smaller companies have higher productivity in their accounts receivable. Comparing to the small companies, the market to book ratio in the large companies are lower since those companies have more equities.

In addition to conducting different tests on the number of employees, researchers also conduct different tests that examine the type of company. The following are the results of data processing carried out for different types of company tests:

Table 6 Mean Difference Test Based on Industry Groups

\begin{tabular}{|c|c|c|c|c|c|c|c|c|c|c|}
\hline \multirow[t]{3}{*}{ Dependent Variable } & $\begin{array}{c}\text { FSIZE } \\
\text { Assets }\end{array}$ & $\begin{array}{c}\text { FSIZE } \\
\text { Rev. }\end{array}$ & ROA & $\begin{array}{l}\text { Profit } \\
\text { Margin }\end{array}$ & $\begin{array}{c}\text { Ln } \\
\text { Market } \\
\text { Value }\end{array}$ & $\begin{array}{l}\text { Debt } \\
\text { Ratio }\end{array}$ & $\begin{array}{c}\text { Ln } \\
\text { Market } \\
\text { Book } \\
\text { Ratio }\end{array}$ & $\begin{array}{l}\text { Rec. } \\
\text { Turn. }\end{array}$ & $\begin{array}{l}\text { Asset } \\
\text { Turn. }\end{array}$ & $\begin{array}{c}\text { Ln NFA } \\
\text { Turn. }\end{array}$ \\
\hline & $\begin{array}{l}\text { Mean } \\
\text { Diff. }\end{array}$ & $\begin{array}{c}\text { Mean } \\
\text { Diff. }\end{array}$ & $\begin{array}{l}\text { Mean } \\
\text { Diff. }\end{array}$ & $\begin{array}{l}\text { Mean } \\
\text { Diff. }\end{array}$ & $\begin{array}{l}\text { Mean } \\
\text { Diff. }\end{array}$ & $\begin{array}{c}\text { Mean } \\
\text { Diff. }\end{array}$ & $\begin{array}{l}\text { Mean } \\
\text { Diff. }\end{array}$ & $\begin{array}{l}\text { Mean } \\
\text { Diff. }\end{array}$ & $\begin{array}{c}\text { Mean } \\
\text { Diff. }\end{array}$ & $\begin{array}{l}\text { Mean } \\
\text { Diff. }\end{array}$ \\
\hline & $\begin{array}{c}\text { Sig. (t- } \\
\text { Test) }\end{array}$ & $\begin{array}{c}\text { Sig. (t- } \\
\text { Test) }\end{array}$ & $\begin{array}{c}\text { Sig. (t- } \\
\text { Test) }\end{array}$ & $\begin{array}{c}\text { Sig. (t- } \\
\text { Test) }\end{array}$ & $\begin{array}{c}\text { Sig. (t- } \\
\text { Test) }\end{array}$ & $\begin{array}{c}\text { Sig. (t- } \\
\text { Test) }\end{array}$ & $\begin{array}{c}\text { Sig. (t- } \\
\text { Test) }\end{array}$ & $\begin{array}{c}\text { Sig. (t- } \\
\text { Test) }\end{array}$ & $\begin{array}{c}\text { Sig. (t- } \\
\text { Test) }\end{array}$ & $\begin{array}{c}\text { Sig. (t- } \\
\text { Test) }\end{array}$ \\
\hline Manufacturing - Non- & 0.346 & 0.553 & 0.643 & -1.865 & 0.544 & 0.032 & 0.124 & 0.36 & 0.112 & -0.088 \\
\hline Manufacturing & 0.366 & 0.119 & 0.928 & 1.000 & 0.117 & 0.465 & 0.558 & 0.904 & 0.134 & 0.887 \\
\hline Manufacturing - & -2.239 & -0.18 & 8.977 & -14.869 & -1.714 & 0.161 & 0.453 & 9.009 & 0.723 & -1.13 \\
\hline Banking & 0.000 & 0.789 & 0.000 & 0.000 & 0.000 & 0.000 & 0.002 & 0.000 & 0.000 & 0.000 \\
\hline Non-Manufacturing - & -2.585 & -0.734 & 8.333 & -13.004 & -2.258 & 0.13 & 0.329 & 8.649 & 0.611 & -1.042 \\
\hline Banking & 0.000 & 0.000 & 0.000 & 0.000 & 0.000 & 0.000 & 0.008 & 0.000 & 0.000 & 0.000 \\
\hline
\end{tabular}

The FSIZE (total assets) of manufacturing companies tend to worth less than the FSIZE (total asset) of banking companies. Likewise, non-manufacturing companies have smaller FSIZE (total asset) than FSIZE (total asset) of banking companies. This shows that banking companies' smaller FSIZE (total asset) is greater than the manufacturing and non-manufacturing companies.

FSIZE revenue from manufacturing companies has no difference from non-manufacturing and banking companies. Non-manufacturing companies have less value than banking FSIZE revenue. The results of banking company FSIZE revenue are equal to the value of the FSIZE assets of non-manufacturing companies with greater value, but there is no difference with manufacturing companies in terms of FSIZE revenue.

In terms of profitability, manufacturing companies have greater ROA than banking companies. CSR engagements enable the manufacturing companies to win suppliers' trust which leads to the enhancement of production speed and quality, thus companies may improve their profit (Nyarku \& Oduro, 2019). Nonmanufacturing companies also have greater ROA than banking companies. It can be concluded that the ROA of banking companies are smaller than the manufacturing and non-manufacturing companies. The ROA results are inversely related to profit margins. The profit margin of manufacturing companies is lower than the profit margin of banking companies. Non-manufacturing companies have a smaller profit margin than banking companies. The result of this profit margin is concluded that banking companies have a higher profit margin than manufacturing and non-manufacturing companies.

The market value of manufacturing companies will have a smaller value than banking companies; however, manufacturing companies' market book ratios are more substantial than banking companies. The market value of non-manufacturing companies is lower than banking companies, while market book ratios of 
non-manufacturing companies are higher than banking companies. Thus, banking companies tend to have higher market value than manufacturing and non-manufacturing companies. Conversely, with the market book ratio, banking companies tend to have smaller values than manufacturing and non-manufacturing companies.

Debt ratios of manufacturing and non-manufacturing companies are higher than banking companies. Therefore, banking companies have a smaller debt ratio than manufacturing and non-manufacturing companies.

Manufacturing and non-manufacturing companies have a higher receivable turnover and higher asset turnover than banking companies. Therefore, it can be concluded that receivable turnover and banking company asset turnover is smaller than manufacturing and non-manufacturing companies. If seen from the NFA turnover variable, the results are inversely related. Manufacturing and non-manufacturing companies have a lower NFA turnover than banking companies; thus, banking companies have higher NFA turnover than manufacturing and non-manufacturing companies.

By analysing at the results of the leverage dimension test, the hypotheses state that there are differences in the leverage dimensions of companies which consistently follow the ISRA and those which did not follow it consistently ( $\mathrm{H} 3 \mathrm{a}$ ). The results of the debt ratio that show significant negative difference. This result is in line with previous research by Giannarakis (2014). Companies' debt ratio which discloses CSR and consistently followed ISRA are smaller than companies which disclose CSR but did not consistently follow ISRA; it can be concluded that companies which consistently follow ISRA have better economic conditions. That is, only a small portion of the companies' assets are financed by debt. Investors or creditors will feel safer if they are funding companies which are actively participating in the ISRA due to lower credit risks (Hsu \& Chen, 2015).

The variable debt-equity ratio (DER) has a negative significant. DER with a value below 1.00 , indicates that a company has smaller debt than its capital. Significant results start to show for companies which disclose CSR and consistently follow the ISRA. The lower the DER of the company, the more the certainty of the company to pay its long-term obligations. Sheikh (2018) argues that firms that have a higher score on CSR have lower leverage ratios. These results are similar to Verwijmeren \& Derwall (2010); Bae et al. (2011). Besides, things that must be considered by companies are engaging in financial services lead to higher DER because most of the funds are managed by third-party funds which are considered as debt. The higher the third party's involvement in capital management, the higher the probability of getting a higher profit. Shareholders prefer lower DER companies because the ability to provide dividends to shareholders will be higher. This will lessen the concern for stakeholders about investing in companies that consistently follow the ISRA which are more protected from the risk of bankruptcy (Hsu \& Chen, 2015).

Furthermore, the hypothesis states that there are differences in the leverage dimensions in ISRA participants according to the business sector $(\mathrm{H} 3 \mathrm{~b})$. According to the analysis results which have been carried out, companies which are classified as manufacturing and non-manufacturing will have larger debt ratio than banking companies. The majority of manufacturing and non-manufacturing companies have their assets financed by debt. Looking at the sample of companies taken by the majority engaged in manufacturing and mining, it requires assets at a great cost. It does not rule out the possibility that debt from manufacturing and non-manufacturing companies will be higher. So that the debt ratio of manufacturing and non-manufacturing companies can be higher than banking companies which focus on financial services with lower asset costs.

Finally, the hypotheses state that there are differences in the leverage dimensions of ISRA participants based on company size $(\mathrm{H} 3 \mathrm{C})$. Companies which have $<2,000$ employees will have higher debt ratio than companies that have $>10,000$ employees. Companies which consistently followed ISRA with $>10,000$ 
employees have better economic conditions. The respective companies can fund existing assets with minimal debt.

Moving to financial ratios and existing hypotheses, there are differences in the profitability dimensions between companies which are consistently and inconsistently took part in ISRA (H1a). The results of the bootstrap test show that the value of sig. ROA 0.119, ROE 0.402, and profit margin 0.148 have no significant difference between companies which consistently followed the ISRA with those which did not. It is a common thought that most of the companies are profit-oriented; therefore profit is not a significant factor that can drive the companies to do more social activities (Asmeri et al., 2017).

The second hypothesis in the profitability dimension states that there are differences in ISRA participants based on the business sector ( $\left.\mathrm{H}_{1} \mathrm{~b}\right)$. Manufacturing and non-manufacturing companies have higher ROA than banking companies. Investors will tend to invest in companies which continue to experience an increase in ROA because of the higher the ROA, the greater the ability of the company to use all existing assets to maximize net income. Thus, the refund rate will swiftly rotate again. Mahbuba \& Farzana (2013) imply that CSR has a significant impact on profitability, which means CSR positive influence in short terms, and the return will be even higher in the long-term. In terms of profit margin ratio, manufacturing and non-manufacturing companies are smaller than banking companies. Macharia \& Gatuhi (2013) argue that higher profit margin implies that the company has more cash inventory, and the return will increase. Banking companies which followed ISRA can generate net income purely from business operations. The operational costs contained are effectively able to be covered by company profits and the ability to achieve a higher percentage of net income.

The third hypothesis from profitability dimension shows that there are differences between ISRA participants based on company size (H1c). This result is according to the research of Giannarakis (2014); Anas et al. (2015). Companies' ROA, which have < 2,000 employees, will be far higher than companies which have 2,000-10,000 employees and even higher than 10,000 employees. From the perspective of profit margin ratio, it is also stated that the company's profit margins, which $<2,000$ employees are higher than companies with 2,000-10,000 employees and $>10,000$ employees. Companies generate higher profits because the value of the resources to create a product are small, and the company can effectively cut costs-existing costs to maximize profits.

The hypothesis states that there are differences in market dimensions between companies which consistently and inconsistently followed ISRA ( $\mathrm{H} 2 \mathrm{a})$. Bootstrap test results show that there is no significant difference between companies that are consistent with companies that do not consistently follow the ISRA. In conclusion, the market is not too concerned about companies that conduct active CSR or not. However, in (Rhou et al., 2016), stakeholders respond positively to companies with active CSR. The second hypothesis states that there are differences in market dimensions of ISRA participants based on the business sector ( $\mathrm{H} 2 \mathrm{~b})$. Looking at the results of the multivariate test, the market value of manufacturing and non-manufacturing companies is lesser than banking companies. Zaccheaus et al. (2014) CSR performance in manufacturing companies are not related to stock prices because investors used the sustainability report only as a guide to investing, but investors tend to use financial statements to consider. While the market book ratio of manufacturing and non-manufacturing companies is larger than banking companies. Market value is a reflection of the company size, which can influence investors in making decisions to buy, sell, or hold their shares. Bae et al. (2011) companies that carry out CSR will help companies improve their image to interact with investors, so investors intend to invest in the company, and this can build a favourable share price while Izzo \& di Donato (2012) stated that the negative market response in the stock prices of companies that do CSR is due to high financial pressures and high risk. Banking companies which consistently followed ISRA are seen as having more volatile fluctuations, making the stock market value higher. The bank companies that have a high- 
profit margin has a significant effect on investors in assessing the market so that it has an impact on stock market value (Macharia \& Gatuhi, 2013). However, external parties provide a more accurate assessment of the book value of manufacturing and non-manufacturing companies. This is due to investors' optimistic approach that manufacturing and non-manufacturing companies which actively participate in ISRA to have a more dynamic business process and to be developed in the future. Therefore, manufacturing and nonmanufacturing companies are considered growth stocks.

The third hypothesis from the market dimension perspective states that there are differences in market dimensions between ISRA participants based on company size $(\mathrm{H} 2 \mathrm{C})$. Companies with the highest number of employees have larger market values when compared to companies that the smaller ones. Conversely, from the market book ratios, companies with the highest number of employees are lower than companies with the smallest number of employees. Investors tend to give positive response to companies which consistently followed ISRA with the largest number of employees, but investors are not optimistic enough to provide considerable ratings to companies with >10,000 employees even though consistently followed ISRA.

Lastly, the hypothesis of asset management states that there are differences between ISRA participants (consistent and inconsistent) ( $\mathrm{H} 4 \mathrm{a}$ ). Companies' receivable turnover of those which consistently followed ISRA is larger than those who did not consistently follow ISRA. Companies which consistently followed ISRA have quicker receivables to be billed, so the company can quickly convert the account receivable into cash.

The second hypothesis signifies that there are differences in the asset management dimension of ISRA participants based on the business sector $\left(\mathrm{H}_{4} \mathrm{~b}\right)$. Manufacturing and non-manufacturing companies have a better receivable turnover and higher asset turnover than banking companies. Looking at the NFA turnover ratio, manufacturing and non-manufacturing companies have smaller NFA turnover than banking companies. Manufacturing and non-manufacturing companies which were actively involved in ISRA are better at converting receivables into cash than banking companies. This case may be affected by banking companies which tend to provide long term credits and make the acquisition in cash to require a longer time-scape than manufacturing and non-manufacturing companies. The same case with asset turnover owned by manufacturing and non-manufacturing companies which actively participated in ISRA tend to be more effective in using assets to support sales than banking companies. Whereas in NFA turnover, banking companies are higher because assets owned by banks tend to require more than one strategic building to support operations and customer satisfaction.

Finally, asset management dimension shows that there are differences in the asset management dimensions between ISRA participants based on company size (H4C). Companies which have 2,000-10,000 employees and >10,000 employees show no difference in terms of receivable turnover; however, those companies have lesser value than companies with a smaller number of employees. NFA turnover companies that have the largest number of employees worth more than companies that have $<2,000$ employees and 2,000-10,000 employees. The asset turnover ratio does not show any difference in the companies with any level number of employees. The company which actively follows ISRA with > 2,000 employees have lesser debt turnover because these companies provide a larger amount of debt than companies that have $<2,000$ employees, thus, in terms of arrears and billing to customers, it will be much longer than companies that are less than 2,000 employees. Related to NFA turnover, companies which actively participated in ISRA with > 10,000 employees will be higher, which can be caused by the fulfillment of capacity and asset financing owned. Therefore, the fewer resources, the smaller the capacity and funding needed.

ISRA is considered an activity which can provide sustainable development for company management. Notably, the demand for sustainability reports has become higher because it helps the stakeholders and the community to analyse environmental problems produced by the company. SAM (2012) states that external 
parties can assess companies from dimensions such as profit, planet, and people. Connecting with people is one of the management concerns to create good relationships with employees. Kim et al. (2010) states that CSR has a direct influence on the identity of the companies. Chtourou \& Triki (2017) also says that companies must pay attention to employee relationship so that they can improve company performance. This has become an encouragement for management, especially for companies which consistently follow the ISRA to pay attention to employees and to make employees feel comfortable. When employees feel comfortable, the employees will make their performance to become more productive. Assets owned by the company will be more effectively used so that turnover in the company's performance will be higher as well.

The level of interest of the companies that are actively participating in ISRA tends to be focused on the manufacturing and non-manufacturing sectors. External parties are more optimistic about the performance of manufacturing and non-manufacturing companies. This can be said by looking at investors who are optimistic about determining the company's book value, high debt turnover rate, high ROA, and how manufacturing and non-manufacturing companies are able to optimize their assets to be cost-effective and to have dynamic sales. The NCSR agency noted the rating of Asian companies, especially Indonesia, which managed to score platinum rank, are manufacturing and non-manufacturing companies (NCSR, 2019). This achievement encourages stakeholders to entrust his investment in manufacturing and non-manufacturing companies.

\section{CONCLUSION}

The first hypothesis related to financial ratios used is profitability, market, leverage, and asset management. The related dimensions are tested differently to see the effect of financial performance between companies that consistently followed the ISRA and companies that did not consistently follow the ISRA. Based on the results of the test, the first hypothesis shows to be accepted (positive) because the variable of the company ratio which consistently followed ISRA is different from the company that did not consistently follow the ISRA.

The second hypothesis is conducted on different tests have been conducted by looking at the differences in companies which actively participated in the ISRA. Companies that actively participated in ISRA are divided into three business sectors, namely manufacturing, non-manufacturing, and banking. Likewise, the second hypothesis is accepted because the variables of the ratio of manufacturing and non-manufacturing companies which followed ISRA are different from the banking companies which followed the ISRA. By looking at the list of winners in the last three years of ISRA award, the majority was dominated by manufacturing and nonmanufacturing companies, making external parties to be more optimistic to companies which follow ISRA in manufacturing and non-manufacturing sectors.

The final hypothesis is conducted on different tests have been carried out by looking at the differences in companies that actively participated in the ISRA. Companies which actively participated in ISRA are divided into 3 classifications of the number of employees which are less than 2,000, 2,000 to 10,000, and more than 10,000. The third hypothesis is declared to be acceptable because companies that have less than 2,000, 2,000 to 10,000 employees, and more than 10,000 have differences in financial performance. Companies which are aware that employees are part of the company's assets that need to be considered have better financial performances.

From all the results of this research, companies that have disclosed sustainable reports but are not actively participating in the ISRA must consider the effect of ISRA for companies. Outside parties will be more interested in companies which actively participate in ISRA. Especially companies engaged in the manufacturing and non-manufacturing sector, in which from the data sample, the majority of companies that are involved in 
mining require corporate responsibility. If the company can get high ranks and become the winner as the best sustainable report in the ISRA competition, the external party will assume that the company cares about the environment and the surrounding community. Companies get the legitimacy from the society from its social concern activities. Companies which are developed well and sustain are companies that can protect the environment. Therefore, there is a balance between profits with environmental conditions and public trust. Research related to the benefits of following this ISRA is still minimal; consequently, further research can explore more about the factors that influence company interest in the ISRA competition and the benefits of ISRA for stakeholders.

\section{ORCID}

Hatane Semuel (1D) https://orcid.org/0000-0002-5266-0137

Saarce Elsye Hatane (10) https://orcid.org/0000-0002-3797-1623

Josua Tarigan (1D) https://orcid.org/0000-0003-2729-7433

\section{REFERENCES}

Anas, A., Rashid, H. M. A., \& Annuar, H. A. (2015). The Effect of Award on CSR Disclosures in Annual Reports of Malaysian PLCs. Social Responsibility Journal, 11(4), 831-852. https://doi.org/10.1108/SRJ-02-2013-0014

Asmeri, R., Alvionita, T., \& Gunardi, A. (2017). CSR Disclosures in the Mining Industry: Empirical Evidence from Listed Mining Firms in Indonesia. Indonesian Journal of Sustainability Accounting and Management, 1(1), 16-22. https://doi.org/10.28992/ijsam.v1i1.23

Bae, K.-H., Kang, J.-K., \& Wang, J. (2011). Employee Treatment and Firm Leverage: A Test of the Stakeholder Theory of Capital Structure. Journal of Financial Economics, 100(1), 130-153. https://doi.org/10.1016/j.jfineco.2010.10.019

Bajic, S., \& Yurtoglu, B. (2018). Which Aspects of CSR Predict Firm Market Value? Journal of Capital Markets Studies, 2(1), 50-69. https://doi.org/10.1108/JCMS-10-2017-0002

Bilbao-Terol, A., Arenas-Parra, M., Alvarez-Otero, S., \& Cañal-Fernández, V. (2019). Integrating Corporate Social Responsibility and Financial Performance. Management Decision, 57(2), 324-348. https://doi.org/10.1108/MD-03-2018-0290

Chakroun, R., Matoussi, H., \& Mbirki, S. (2017). Determinants of CSR Disclosure of Tunisian Listed Banks: A MultiSupport Analysis. Social Responsibility Journal, 13(3), 552-584. https://doi.org/10.1108/SRJ-04-2016-0055

Chtourou, H., \& Triki, M. (2017). Commitment in Corporate Social Responsibility and Financial Performance: A Study in the Tunisian Context. Social Responsibility Journal, 13(2), 370-389. https://doi.org/10.1108/SRJ-052016-0079

Cormier, D., Ledoux, M., \& Magnan, M. (2011). The Informational Contribution of Social and Environmental Disclosures for Investors. Management Decision, 49(8), 1276-1304. https://doi.org/10.1108/00251741111163124

de Villiers, C., \& Marques, A. (2016). Corporate Social Responsibility, Country-Level Predispositions, and the Consequences of Choosing a Level of Disclosure. Accounting and Business Research, 46(2), 167-195. https://doi.org/10.1080/00014788.2015.1039476

Duff, A. (2017). Corporate Social Responsibility as a Legitimacy Maintenance Strategy in the Professional Accountancy Firm. The British Accounting Review, 49(6), 513-531. https://doi.org/10.1016/j.bar.2017.08.001

El Ghoul, S., Guedhami, O., Kwok, C. C. Y., \& Mishra, D. R. (2011). Does Corporate Social Responsibility Affect the Cost of Capital? Journal of Banking and Finance, 35(9), 2388-2406. https://doi.org/10.1016/j.jbankfin.2011.02.007 
Giannarakis, G. (2014). The Determinants Influencing the Extent of CSR Disclosure. International Journal of Law and Management, 56(5), 393-416. https://doi.org/10.1108/IJLMA-05-2013-0021

GRI. (2013). G4 Sustainability Reporting Guidelines. Amsterdam: Global Reporting Initiative.

Hasan, R., \& Yun, T. M. (2017). Theoretical Linkage between Corporate Social Responsibility and Corporate Reputation. Indonesian Journal of Sustainability Accounting and Management, 1(2), 80-89. https://doi.org/10.28992/ijsam.v1i2.32

Hsu, F. J., \& Chen, Y.-C. (2015). Is a Firm's Financial Risk Associated with Corporate Social Responsibility? Management Decision, 53(9), 2175-2199. https://doi.org/10.1108/MD-02-2015-0047

Hussain, N. (2015). Impact of Sustainability Performance on Financial Performance: An Empirical Study of Global Fortune (N100) Firms (Working Paper Series No. 1/2015).

Izzo, M. F., \& di Donato, F. (2012). The Relation between Corporate Social Responsibility and Stock Prices: An Analysis of the Italian Listed Companies. SSRN.

Jamali, D. (2014). CSR in Developing Countries through an Institutional Lens. In G. Eweje (Ed.), Corporate Social Responsibility and Sustainability: Emerging Trends in Developing Economies (Critical Studies on Corporate Responsibility, Governance and Sustainability) (8th ed., pp. 21-44). Emerald Publishing Limited. https://doi.org/10.1108/S2043-905920140000008005

Jizi, M. (2017). The Influence of Board Composition on Sustainable Development Disclosure. Business Strategy and the Environment, 26(5), 640-655. https://doi.org/10.1002/bse.1943

Khojastehpour, M., \& Johns, R. (2014). The Effect of Environmental CSR Issues on Corporate/Brand Reputation and Corporate Profitability. European Business Review, 26(4), 330-339. https://doi.org/10.1108/EBR-032014-0029

Kim, H.-R., Lee, M., Lee, H.-T., \& Kim, N.-M. (2010). Corporate Social Responsibility and Employee-Company Identification. Journal of Business Ethics, 95(4), 557-569. https://doi.org/10.1007/s10551-010-0440-2

Kim, Y., Li, H., \& Li, S. (2014). Corporate Social Responsibility and Stock Price Crash Risk. Journal of Banking and Finance, 43, 1-13. https://doi.org/10.1016/j.jbankfin.2014.02.013

Kurniawan, P. S. (2018). An Implementation Model of Sustainability Reporting in Village-Owned Enterprise and Small and Medium Enterprise. Indonesian Journal of Sustainability Accounting and Management, 2(2), 90106.

Lin, C.-S., Chang, R.-Y., \& Dang, V. (2015). An Integrated Model to Explain How Corporate Social Responsibility Affects Corporate Financial Performance. Sustainability, 7(7), 8292-8311. https://doi.org/10.3390/su7078292

Macharia, P. I., \& Gatuhi, S. K. (2013). Effect of Financial Performance Indicators on Market Price of Shares in Commercial Banks of Kenya. International Journal of Management and Business Studies, 3(3), 57-60.

Mahbuba, S., \& Farzana, N. (2013). Corporate Social Responsibility and Profitability: A Case Study on Dutch Bangla Bank Ltd. International Journal of Business and Social Research, 3(4), 139-145.

Martin, R., Yadiati, W., \& Pratama, A. (2018). CSR disclosure and Company Financial Performance: Do High and Low-Profile Industry Moderate the Result? Indonesian Journal of Sustainability Accounting and Management, 2(1), 15-24.

Mehralian, G., Nazari, J. A., Zarei, L., \& Rasekh, H. R. (2016). The Effects of Corporate Social Responsibility on Organizational Performance in the Iranian Pharmaceutical Industry: The Mediating Role of TQM. Journal of Cleaner Production, 135, 689-698. https://doi.org/10.1016/j.jclepro.2016.06.116

NCSR. (2019). Asia Sustainability Reporting Rating (Asia SR Rating) 2018. Retrieved March 5, 2019, from https://www.ncsr-id.org/2019/02/12/sustainability-reporting-awards-sra-2018/

Nyarku, K. M., \& Oduro, S. (2019). The Mediating Effect of Supplier Relationship Management on CSR and Marketing Performance Relationship. Indonesian Journal of Sustainability Accounting and Management, 3(1), 1-13. https://doi.org/10.28992/ijsam.v3i1.58

Nyeadi, J. D., Ibrahim, M., \& Sare, Y. A. (2018). Corporate Social Responsibility and Financial Performance Nexus: Empirical Evidence from South African Listed Firms. Journal of Global Responsibility, 9(3), 301-328. https://doi.org/10.1108/JGR-01-2018-0004 
Pérez, A., Martínez, P., \& del Bosque, I. R. (2013). The Development of a Stakeholder-Based Scale for Measuring Corporate Social Responsibility in the Banking Industry. Service Business, 7(3), 459-481. https://doi.org/10.1007/s11628-012-0171-9

Reddy, K., \& Gordon, L. W. (2010). The Effect of Sustainability Reporting on Financial Performance: An Empirical Study using Listed Companies. Journal of Asia Entrepreneurship and Sustainability, 6(2), 19-42.

Rhou, Y., Singal, M., \& Koh, Y. (2016). CSR and Financial Performance: The Role of CSR Awareness in the Restaurant Industry. International Journal of Hospitality Management, 57, 30-39. https://doi.org/10.1016/j.ijhm.2016.05.007

Romero, S., Fernandez-Feijoo, B., \& Ruiz, S. (2014). Perceptions of Quality of Assurance Statements for Sustainability Reports. Social Responsibility Journal, 10(3), 480-499. https://doi.org/10.1108/SRJ-10-20120130

SAM. (2012). The Sustainability Yearbook 2012. Zurich: SAM Sustainable Asset Management USA, Inc.

Sekaran, U., \& Bougie, R. (2016). Research Methods for Business: A Skill Building Approach (7th ed.). Chichester: John Wiley \& Sons, Inc.

Servaes, H., \& Tamayo, A. (2013). The Impact of Corporate Social Responsibility on Firm Value: The Role of Customer Awareness. Management Science, 59(5), 1045-1061. https://doi.org/10.1287/mnsc.1120.1630

Sheikh, S. (2018). Corporate Social Responsibility, Product Market Competition, and Firm Value. Journal of Economics and Business, 98, 40-55. https://doi.org/10.1016/j.jeconbus.2018.07.001

SWAOnline. (2013). Perusahaan Pembuat Laporan Keberlanjutan Kian Banyak di Indonesia. Retrieved February 10, 2019, from https://swa.co.id/swa/trends/business-research/perusahaan-pembuat-laporankeberlanjutan-kian-banyak-di-indonesia

Syamni, G., Wahyuddin, Damanhur, \& Ichsan. (2018). CSR and Profitability in IDX Agricultural Subsectors. In Proceedings of MICOMS 2017 (Emerald Reach Proceedings Series) (1st ed., pp. 511-517). Emerald Publishing Limited. https://doi.org/10.1108/978-1-78756-793-1-00034

Verwijmeren, P., \& Derwall, J. (2010). Employee Well-Being, Firm Leverage, and Bankruptcy Risk. Journal of Banking and Finance, 34(5), 956-964. https://doi.org/10.1016/j.jbankfin.2009.10.006

Zaccheaus, S. A., Oluwagbemiga, O. E., \& Olugbenga, O. M. (2014). Effects of Corporate Social Responsibility Performance (CSR) on Stock Prices: Empirical Study of Listed Manufacturing Companies in Nigeria. IOSR Journal of Business and Management, 16(8), 112-117. 